Primljen / Received: 8.7.2011.

Ispravljen / Corrected: 5.10.2012.

Prihvaćen / Accepted: 17.10.2012.

Dostupno online / Available online: 15.11.2012.

\section{Analysis of lightweight aggregate concrete beams}

\section{Author:}

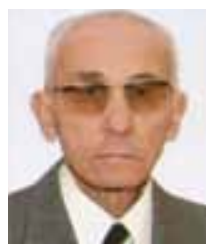

Prof.emer. Ivan Tomičić, Ph.D. CE

University of Zagreb

Faculty of Civil Engineering
Ivan Tomičić

Professional paper

\section{Analysis of lightweight aggregate concrete beams}

The possibility of using the lightweight aggregate concrete for construction of reinforcedconcrete elements subjected to bending stress is presented in the paper. The adequacy of this material for construction of low and high buildings, bridges, industrial facilities, and water engineering facilities, especially in earthquake-prone areas, is presented and substantiated. Computation procedures given for normal-weight concrete elements subjected to bending stress, can also be applied, with minor modifications, to lightweight concrete structures..

Key words:

lightweight aggregate concrete, computation procedure, load-bearing capacity, ductility, deflection, cracking

Stručni rad

\section{Ivan Tomičić}

\section{Proračun greda od lakoagregatnog betona}

U radu je prikazana mogućnost primjene lakoagregatnog betona u gradenju armiranobetonskih elemenata naprezanih savijanjem. Obrazložena je opravdanost uporabe tog materijala za gradenje niskih i visokih zgrada, mostova, industrijskih objekata te hidrotehničkih građevina, osobito u seizmičkim područjima. Postupci proračuna, dani za elemente naprezane savijanjem, od normalno teškog betona mogu se, uz manje izmjene, primjenjivati i za konstrukcije od lakog betona.

Ključne riječi:

lakoagregatni beton, postupak proračuna, nosivost, duktilnost, progib, raspucavanje

Fachbericht

\section{Ivan Tomičić}

\section{Berechnung eines Trägers aus Leichtbeton}

In der Arbeit wird die Möglichkeit der Verwendung von Leichtbeton beim Bau von Stahlbetonelementen unter Biegungsspannung dargestellt. Die Rechtfertigung der Verwendung dieses Materials zum Bau von niedrigen und hohen Gebäuden, Brücken, Industrieanlagen und hydrotechnischen Bauwerken vor allem in seismischen Gebieten wird erläutert. Die Berechnungsverfahren für Elemente unter Biegungsspannung aus normal schwerem Beton können mit kleineren Anpassungen auch für Leichtbetonkonstruktionen übernommen werden.

Schlüsselwörter:

Leichtbeton, Berechnungsverfahren, Tragfähigkeit, Duktilität, Biegung, Dekrepitation 


\section{Introduction}

In addition to the traditional concrete made with normalweight aggregate (NWC), an increasing interest is currently shown, both in our country and worldwide, for good quality lightweight concrete types such as the one made of lightweight aggregate (LWC). Because of their proven advantages, LWC structures are now used in the construction of low-rise and high-rise buildings, bridges, industrial facilities, sea vessels, and coastal systems. A growing interest for LWC structures is unfortunately not followed by appropriate regulations. Regulations most often in use are American standards $\mathrm{ACl} 213 \mathrm{R}-3$ [1] and $\mathrm{ACl}$ 318-05 [2] which contain basic rules for LWC structures and take into account their potential use in the future. On the other hand, many developed countries do not have regulations, which is explained by the lack of experience in the use of LWC. The reason lies in the lack of knowledge about production of the light-weight aggregate concrete, and about benefits associated with its use. Some calculation-based recommendations can be found in the British Standard BS 8110 [3] and in the CEB-FIP model code [5]. A special section about LWC structures has recently been introduced in Eurocode 2 EN 1992-1-1 2004 [4], which will certainly contribute to a wider use of this material.

Studies recently conducted at the National University in Singapore [6] have given a new insightinto behaviour of LWC structures, and point tonovel possibilities for analyzing systems made of this material. Results of these studies, and their application in the calculation of LWC beams, will also be presented and substantiated in this paper. Rules applied in the analysis of structures made of normal-weight concrete are alsoused in the analysis of LWC beams subjected to flexural stress, but some parameters have to be based on the study of behaviour of LWC beams. Calculation procedures presented in this paper are based on the European standard EN 19921-1 [4] and, to a lesser extent, on the American building code requirements $\mathrm{ACl}$ 318-05 [2].

\section{Experimental and analytic studies}

Studies made by L.H. Sina et al [6], aimed at analyzing improved properties of lightweight aggregate concrete and its practical use, will briefly be presented in this paper. Based on experimental analyses, the researchers have obtaineda quantity of data that is sufficient for determination of parameters needed in the analysis according to limit states of bearing capacity and usability, such as the compressive strength $f_{c k^{\prime}}$ coefficients of reinforcement of tensile $\rho$ and compressive $\rho^{\prime}$ areas, and transverse reinforcement, $\rho_{w^{\prime}}$ In addition, sufficient data were provided for the verification of ductility, stiffness, and cracking of lightweight aggregate (LWC) beams.

\subsection{Experimental studies}

Researchers tested $21 \mathrm{LWC}$ beams as well as three reference NWC beams, to enable comparison. The beams were divided into five groups so that each relevant parameter can be tested, while other properties in individual groups remained unchanged. The compressive strength varied from 20 to 75 $\mathrm{MPa}$. The value for the coefficient of reinforcement in tensile range amounted to 0.67 and $1.02 \%$.

Beam samples were of rectangular cross section, 150/300 $\mathrm{mm}$, and measured $3.1 \mathrm{~m}$ in length ( $2.8 \mathrm{~m}$ in span). They were subjected to two concentrated forces, spaced symmetrically at $800 \mathrm{~mm}$ intervals within the span. The beams were reinforced with longitudinal reinforcement in the tension and compression range. The transverse reinforcement in form of closed ties was made of wire $10 \mathrm{~mm}$ in diameter. For all beams, the ductile behaviour at bending was ensured by closed ties, by cross section, by their spacing, and by compression reinforcement. The beams were equipped with instruments for measuring deflection, concrete and steel deformation, and curvature in central area, as well as the cracking width at the beam tensionreinforcement level. The load was applied monotonously until the steel yield limit, and further on until failure.

\subsection{Test results and discussion}

The "load-deflection" curves in the centre of the span were obtained for two pairs of beams made of LWC and NWC. The diagrams were described, for both types of concrete, through four different and separate events, namely:

1. cracking due to bending

2. tensile reinforcement failure

3. crushing and separation of protective layer

4. disintegration of compressive concrete.

Test results were compared with predicted results obtained according to $[2,3,4,5]$. The following parameters were predicted: tensile strength at bending $\mathrm{f}_{\mathrm{r}}$ and elastic modulus $\mathrm{E}_{\mathrm{c}}$. They were used so as to obtain the following values: cracking moment, reinforcement yield moment, boundary moment, maximum crack width, and deflection in mid span, using reduction factor $\lambda$ in case of LWC samples.

The cracking of twosamplestaken fromLWC and NWCbeams was compared during and after the loading. The LWC and NWC exhibited exceptional similarity, except in the number of cracks. In case of NWC beams this number varied between 9 and 11, and for LWC it ranged between 10 and 16, at the central part of the span $(800 \mathrm{~mm})$.

The moment registered during occurrence of first cracks, i.e. the $M_{c r^{\prime}}$ is important for estimating inertia, and also for determining beam deflection. The testing has revealed that this value is sensitive to concrete strength and to the quality 
of tensile reinforcement for both beam types. It was observed that LWC beams start to crack earlier when compared to the corresponding NWC beams when the concrete strength is low, whilethe cracking occurs at similar load when the strength is high. The cracking moment $M_{c r}$ needed for comparison was calculated in accordance with relevant regulations. According to most regulations cited, the value of this moment is a function of the predicted tensile strength of concrete subjected to bending $f_{r}$. The $M_{c r}$ calculation proposal given in $[1,2]$ provides equally good results for LWC and NWC beams, and is therefore recommended for practical application, while proposals given in other regulations do not provide correspondent results for both concrete types.

Maximum crack widths registered at LWC and NWC samples were subjected to statistical analysis. It was revealed that these widths are greatly dependant on the coefficient of reinforcement in the tensile area $r$. Installation of a greater number of smaller diameter bars results in greater number of smaller-width cracks. It should be noted that, when identical parameters are used for LWC and NWC, the use of LWC beams results in a greater number of narrow cracks, when compared to NWC beams, which is favourable for durability. In addition, the studies have shown that a good correspondence exists between the registered maximum crack widths, and those obtained using expression from EN 1992-1-1 for both beam types, while results obtained using the Gergely-Lutz equation, as recommended in $[1,2]$, were somewhat less favourable, i.e. prognostic results were lower than the measured ones.

The stiffness and deflection were considered using the "loaddeflection" curve or the "moment-curvature" curve, obtained experimentally. The results have shown that, given the same parameters before and after the cracking, beam stiffnesses are lower in case of LWC beams when compared to the corresponding NWC beams, which is explained by lower modulus of elasticity, $E_{c^{\prime}}$ of $L W C$ beams. Values obtained using regulations $\mathrm{ACl}$ 318-05 and EN 1992-1-1 correspond well to each other, but comparative values obtained through BS 8110 are much lower. The studies have also shown that a certainincrease in the quality of concrete and in the quantity of reinforcement results in higher beam stiffness after cracking, and this regardless of which of the two concrete types is used. However, compressive reinforcement and spacing of ties in the bending zone, do not have a notable influence on beam stiffness. Comparison of deflection values for LWC and NWC beams shows that LWC beam deflections are by 10 percent greater when compared to NWC beam deflections. In summary, the maximum deflection of beams made of both types of concrete, after cracking in mid span, as obtained by testing, is greater than the one predicted using all of the mentioned regulations, when the elastic modulus $\mathrm{E}_{c}$ is applied. Researchers therefore propose that the deflection after cracking should be predicted based on the effective moment of inertia $I_{e}$ and the elastic modulus reduced to one half, i.e. Ec/2, for both LWC and
NWC beams. This is confirmed by the correlation between the experimental and predicted mean deflection values when $\mathrm{I}_{\mathrm{e}}$ is used: 0.99 for NWC beams and 0.91 for LWC beams.

The model of failure and bearing capacity of all beams that weretested for both types of concrete, corresponds tothe one due to bending, when reinforcement is the first to yield (steel reaches its yield limit), which is followed by brittle fracture of compressive concrete. Maximum compressive deformations of concrete, followed by crushing of protective layer, and then by sudden cross-section failure, ranged between 0.0023 and 0.0038 for NWC beams, and between 0.0025 and 0.0038 for LWC beams. However, comparison of NWC and LWC beams with respect to ultimate bearing capacity has revealed very similar maximum deformations of concrete. The comparison of ultimate bearing capacities of NWC and LWC beams, based on identical parameters, has revealed a good correspondence between the two. It was noted thatthe ultimate bearing capacityis influenced by the quantity of tensile reinforcement only, except when the reinforcement coefficient and the concrete quality are high. Just like in case of bending stiffness, the ultimate bearing capacity is not significantly sensitive to the change in compressive reinforcement and spacing of transverse tiesin the zone of maximum bending.

After havinganalyzed the ultimate moment of bearing capacity according to regulations given in $\mathrm{ACl} 318-05$ and EN 1992-1-1, and according to some other national standards, the researchers concluded that ultimate bearing capacities predicted in this way, and obtained viathe moment $M_{u^{\prime}}$ correspond well to each other, and that the correlation between experimental and predicted values is the same for similarLWC and NWC beams. It was concluded that LWC beams subjected to bending can be analyzed in accordance with regulations applicable for NWC beams.

The ductility is considered as a highly desirable property of reinforced-concrete elements and structures because of the bending moment redistribution possibility, absorption of seismic energy, and avoidance of brittle failure, and it must therefore be ensured for LWC beams as well. The property of beams to deform without loss of bearing capacity, i.e. without loss of ductility, is in case of beam systems most often defined by the coefficient of ductility which is the correlation between curvature at concrete failure and curvature at the moment when the stress in tensile reinforcement reaches the yield limit. Researchers studying behaviour of LWC and NWC beams [6] make a distinction between two coefficients of ductility: the first one is the curvature correlation when concrete yields (point at the falling side corresponding to 85 percent limit load), $\mu_{c c^{\prime}}$ and the second one is at final concrete failure, $\mu_{\mathrm{cf}}$. The beam ductility tested via the curvature $\mu_{c c}$ ranged from 1.96 to 4.47 for NWC beams, and from 1.25 to 5.93 for LWC beams.

The coefficient of reinforcement by tensile bars, $\rho$, defined as a part of the balanced reinforcement coefficient $\rho_{\text {bal' }}$ is 


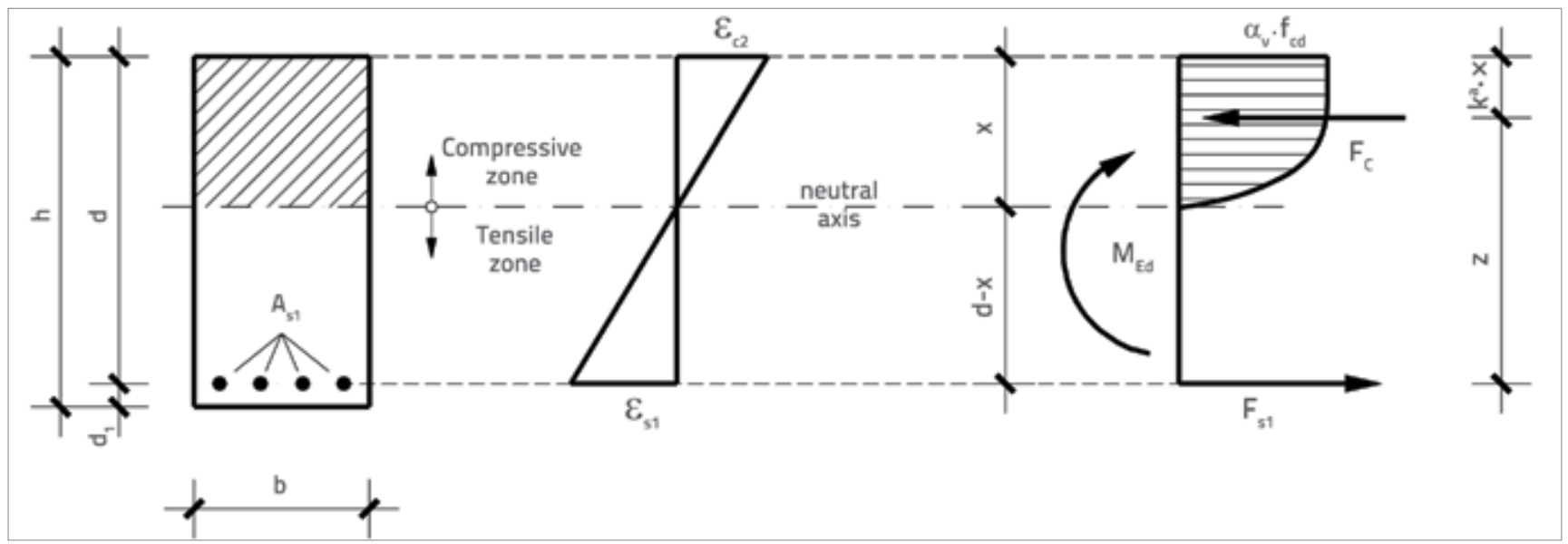

Figure 1. Description of cross-section, stress and strain diagrams, internal and section forces

usually limited by regulationsso that an appropriate ductility can be achieved. It has been determined through experimental studies that the ductility falls with the increase of reinforcement coefficient, $\rho$, in the same way for both LWC and NWC beams. However, the sensitivity of ductility to the correlation $\left(\rho-\rho^{\prime}\right) / \rho_{\text {bal }}$ for double-reinforced cross-sections, or to $\rho / \rho_{\text {bal }}$ for single reinforced cross-sections, is somewhat lower in case of LWC beams when compared to NWC beams, but is in many cases quite similar. That is why the requirement $\rho \leq 0,75 \rho_{\text {bal }}$ aimed at preserving ductility to bending of NWC beams by limiting reinforcement coefficient in tensile zone,can also be applied for LWC beams. Studies have also shown that compressive reinforcement has an influence on ductility because of compressive zone strengthening, which is similar to the corresponding influence of transverse reinforcement. This is due to the effect of being surrounded by closed ties. The tie spacing limitation for NWC, amounting to $d / 4$ (d-static height of cross-section), can also be applied to LWC beams.

The compressive deformation of concrete is of high significance for the prediction of ductility via curvature. According to American regulations $\mathrm{ACl} 318-05$, it amounts to $\varepsilon_{\mathrm{cu}}=0,003$, while it is 0.0035 according to European standards EN 1992-1-1, but for concrete with compressive strength of less than $50 \mathrm{MPa}$. The value $\varepsilon_{\text {сu }}$ reduces with higher strengths. The requirement for NWC contained in $\mathrm{ACl}$ regulations is somewhat more conservative, but is acceptable for LWC elements, and is therefore recommended for elements made of both types of concrete.

In addition, in case of bending moment redistribution according to $[1,2]$, the value of $\rho \leq 0,5 \rho_{\text {bal }}$ is recommended for NWC beams, while $\rho \leq 0,4 \rho_{\text {bal }}$ is recommended for LWC bars, for ductility condition of $\mu_{c c}=3$.

\section{Procedure for calculating beams made of lightweight aggregate concrete}

\subsection{General}

The above presented computation procedure is in accordance with Eurocode 2 as to harmonization of properties of the lightweight aggregate concrete, while American regulations ACl-318-05 offer an alternative possibility and are useful for comparison of computation results for a wider range of concrete strengths. The use of tables and diagrams applicable for NWC is planned [9], while strengths and deformation are applied according to Table 11.3.1 from the new standard EN 1992-1-1. Other data for computation of LWC structures are also applied.

\subsection{Beams subjected to bending moment according EN 1992-1-1}

Experimental studies have shown that rules applied for NWC beams are fully applicable for LWC beams, provided that strengths and deformations according to Table 11.3.1 from [4] are applied. The following equilibrium condition is used for cross-section dimensioning:

$M_{E d}=M_{R d}$

where is design bending moment (1a) and design bearing capacity moment (1b):

$M_{E d}=\sum_{j} \gamma_{g j} \cdot M_{g j}+\gamma_{q} \cdot M_{q 1}+\sum_{i \triangleright 1} \gamma_{q} \cdot \psi_{q i} \cdot M_{q i}+\gamma_{p} \cdot M_{p}$

$M_{R d}=F_{c} \cdot z=F_{s i} z$

The design compressive force in concrete (Figure 1) is:

$F_{c}=f_{l c d} \alpha_{v} \cdot x \cdot b$, gdje je $f_{l c d}=\alpha_{c c} \cdot f_{l c k} / \gamma_{c}$

The design tensile force in reinforcement is:

$F_{s 1}=A_{s 1} \cdot f_{y d}$

The dimensionless bending moment is:

$\mu_{E d}=\frac{M_{E d}}{b \cdot d^{2} \cdot f_{c d}}$

Deformations $\varepsilon_{\mathrm{c} 2}$ and $\varepsilon_{\mathrm{s} 1}$ and coefficient ofthe internal forces leg, $\zeta$, are taken from Tables presented in [9] for the calculated 
$\mu_{\mathrm{Ed}^{\prime}}$ and then the reinforcement is calculated using the following expression:

$$
A_{s 1}=\frac{M_{E d}}{f_{y d} \cdot \zeta \cdot d}
$$

The cross-section is considered ductile if the condition for $(x / d)_{\lim }$ is met, i.e. if the condition of single reinforcement dependent of concrete class is respected. If the beam cross-section does not meet the ductility requirement, then additional tensile and compressive reinforcement must also be calculated:

$A_{s 1}=\frac{M_{R d, \lim }}{z_{\lim } \cdot f_{y d}}+\frac{M_{E d}-M_{R d, \lim }}{\left(d-d_{2}\right) f_{y d}}$

$A_{s 2}=\frac{M_{E d}-M_{R d, \text { lim }}}{\left(d-d_{2}\right) f_{s 2}}$

where $M_{R d, \text { lim }}=\mu_{R d, \text { lim }} \cdot b \cdot d^{2} \cdot f_{c d^{\prime}}$

The analysis of transverse forces for LWC beams does not differ from the corerspondnganalysis for NWC beams.

According to regulations $\mathrm{ACl}-318-05$, the analytic procedure for LWC beams subjected to bending does not differ from that for NWC beams, and so this procedure will not be considered in this text. Also, the cross-section is considered to be a ductile condition for the case of redistribution of bending moments if it meets the condition of reinforcement coefficient $\rho \leq 0,5 \rho_{\text {ba }}$ for NWC beams, and $\rho \leq 0,4 \rho_{\text {bal }}$ for LWC beams, where:

$\rho_{b a l}=0,85 \beta_{1} \cdot f_{c}^{\prime} / f_{y} \frac{-\varepsilon_{c u} \times E_{s}}{-\varepsilon_{c u} \times E_{s}+f_{y}}$

balanced reinforcement condition obtained from the condition of equal bearing capacity with respect to compression and tension (compressive reinforcement is neglected).

\subsection{Limitation of deflection according EN 1992-1-1}

The following condition is applied for the limitation of deflection:

$f_{\text {tot }} \leq f_{g}$

where:

$f_{\text {tot }}=K \cdot I^{2} \frac{1}{r_{\text {tot }}}-$ total deflection

$\frac{1}{r_{\text {tot }}}=\frac{1}{r_{m}}+\frac{1}{r_{c s, m}}-$ total deflection

$f_{g} \quad$ - maximum allowable deflection, as specified in regulations

I - beam span

$\mathrm{K}=1 / \mathrm{K}_{1}$ - coefficient dependent on static system $\mathrm{k}_{1}$ according to [4].

Mean curvature caused by load is $\frac{1}{r_{m}}=\zeta \frac{1}{r_{\|}}+(1-\zeta) \frac{1}{r_{l}}$

where:
$\zeta=1-\beta\left(\frac{M_{c r}}{M_{E d}}\right)^{2}$ - redistribution factor

$M_{c r}=\frac{f_{c c t, m} \cdot b \cdot h^{2}}{6}-$ cracking moment

$M_{E d} \quad$ - bending moment for the combination used

$\frac{1}{r_{\|}}=\frac{\varepsilon_{s}}{d-x} \quad$ - curvature for stress II

$\frac{1}{r_{1}}=\frac{M_{E d}}{0,5 E_{c} \cdot l_{i d}} \quad$ - curvature for stress I

$f_{l c t, m}=\eta_{1} \cdot 0,30 \cdot f_{c k}^{2 / 3}$ for $f_{c k} \leq 50 \mathrm{MPa}$

reduction factor $\eta_{1}=0,4+0,6 \mathrm{w} / 2200$ for $L W C$ beams ( $w$ - bulk density of aggregate)

Mean curvature due to shrinkage is

$\frac{1}{r_{c s, m}}=\zeta \frac{1}{r_{c s, l 1}}+(1-\zeta) \frac{1}{r_{c s, l}}$

where:

$\frac{1}{r_{c s, l}}=\frac{\varepsilon_{c s} \cdot \alpha_{e} \cdot S_{l}}{l_{l}}-$ curvature for stress I

$\frac{1}{r_{c s, I I}}=\frac{\varepsilon_{c s} \cdot \alpha_{e} \cdot S_{\|}}{I_{\|}}$- curvature for stress II

$\alpha_{e}=E_{l c m} / E_{\text {ceff }}$ - elastic modulus ratio

$\varepsilon_{\mathrm{cs}} \quad-$ relative deformation due to concrete shrinkage

Elastic modul of beam $\mathrm{E}_{\mathrm{lcm}}$ is shown by expression (21)

$E_{l c m}=22\left[\left(f_{c k}+8\right) / 10\right]^{0,3} \cdot(\rho / 2200)^{2}(\mathrm{GPa})$

According to American regulations ACl-318-05, the Branson formula is recommended as a means for limiting the deflection.

The condition for limitation is:

$f_{\text {tot }}=f_{k}+f_{d} \leq f_{g}$

Deflection due to short-term load

$f_{k}=K \frac{M_{k} \cdot l^{2}}{l_{e} \cdot E_{c m} \cdot 0,5}$

where:

$M_{k} \quad$ - maximum bending moment of a static system subjected to short-term load,

$K=1 / k_{1}$ - coefficient dependent on static system $\left(k_{1}-\right.$ table in [8]): 
$\mathrm{I}_{\mathrm{e}}=\left(\frac{\mathrm{M}_{\mathrm{cr}}}{M_{\mathrm{a}}}\right)^{3} \mathrm{I}_{\mathrm{g}}+\left[1-\left(\frac{\mathrm{M}_{\mathrm{cr}}}{M_{\mathrm{a}}}\right)^{3}\right] \mathrm{I}_{\mathrm{cr}}$

where:

$M_{c r}=\frac{f_{r} \cdot l_{g}}{h-x}-$ cracking moment

$M_{a}$ - maximum moment of an element for service load

$\mathrm{I}_{\mathrm{cr}}$ - moment of inertia in the cracking zone

$f_{r}=0,62 \lambda \sqrt{f_{c}^{\odot}}$ - tensile strength at bending

$\lambda$ - reduction factor for LWC beams ( $\lambda=0.85$ for all types of lightweight concrete)

$E_{c}=0,043 \rho^{3 / 2} \cdot f_{c}^{\oplus 1 / 2}(\mathrm{MPa})$

Deflection due to long-term load

$f_{d}=K_{r} \cdot \varphi\left(t, t_{o}\right) f_{k d}$

where:

$\mathrm{K}_{\mathrm{r}}=1,0-0,6 \frac{\mathrm{A}_{\mathrm{s} 2}}{\mathrm{~A}_{\mathrm{s} 1}} \geq 0,4 \quad$ - creep and shrinkage are included

$K_{r}=0,85-0,45 \frac{A_{s 2}}{A_{s 1}} \geq 0,4-$ creep is included

$\varphi\left(t, t_{0}\right) \quad$ - creep coefficient.

The meaning of some widely used symbols is presented in detail in [8].

\subsection{Limitation of cracking according EN 1992-1-1}

The following condition is applied for limitation of cracking:

$w_{k} \leq w_{g}$

where:

$w_{k}$ - typical crack width

$w_{g}$ - maximum crack width specified in regulations.

The mean deformation is defined according to the following expression:

$w_{k}=s_{r, \max }\left(\varepsilon_{s m}-\varepsilon_{c m}\right)$

Consequently:

$\varepsilon_{s m}-\varepsilon_{c m}=\frac{\sigma_{s}-k_{1} \frac{f_{c t, e f f}}{\rho_{p, \text { eff }}}\left(1+\alpha_{e} \rho_{p, \text { eff }}\right)}{E_{s}} \geq 0,6 \frac{\sigma_{s}}{E_{s}}$

$\sigma_{s} \quad$ - stress in compressive reinforcement,

$\alpha_{\mathrm{e}}-$ ratio $\mathrm{E}_{\mathrm{s}} / \mathrm{E}_{\mathrm{cm}}$

$\rho_{\mathrm{p}, \mathrm{eff}}$ - ratio of the reinforcement area to the participating tensile area of the cross section $\left(A_{s} / A_{c \text { fff }}\right)$

$A_{\text {ceff }}$ - participating tensile area of the cross section

$k_{t} \quad$ - factor dependent on load duration $\mathrm{k}_{\mathrm{r}}=0,6 \quad$ - for short-term load

$k_{r}=0,4 \quad$ - for long-term load

The maximum crack spacing is obtained according to the expression that is dependent on the main reinforcing bars spacing:

$s_{r, \max }=k_{3} \cdot c+k_{1} \cdot k_{2} \cdot k_{4} \cdot \varphi / \rho_{p, \text { eff }}$, if the bar spacing is $\geq 5\left(c+\frac{\varphi}{2}\right)(31 a)$

$S_{r, \max }=1,3(h-x)_{1}$, if the bar spacing is $>5\left(c+\frac{\varphi}{2}\right)$

At that:

$\phi \quad$ - is bar diameter

c - protective layer thickness

$\mathrm{k}_{1}$ - adhesion coefficient

$\mathrm{k}_{2}$ - coefficient that takes into account distribution of deformations ( $k_{2}=0,5$ - bending; $k_{2}=1,0-$ tension).

The coefficients $k_{3}$ and $k_{4}$ are defined according to [4] and amount to: $k_{3}=3,4 ; k_{4}=0,425$.

The recommendation is given, according to [2], to use the Gergely-Lutz formula, obtained on the basis of a great number of experiments. The procedure is fast and sufficiently accurate for practical applications. It is destined for beams reinforced with corrugated steel. According to [6], it can be applied for LWC beams just as adequately as for NWC beams. This has been confirmed through experiments.

The following expression is proposed for beams subjected to bending:

$w_{\max }=11,0 \frac{h_{2}}{h_{1}} \sigma_{s} \sqrt[3]{A \cdot d^{\prime}} \cdot 10^{-6}(\mathrm{~mm})$

where:

$\sigma_{s} \quad-$ stress in reinforcement in the cracking zone, for service load

$A=2 d^{\prime} \times s \quad$ - surface gravitating to one bar (centric tension)

$A=2 c \times b / n$-concrete surface considered symmetrically taking into account the centre of gravity of tensile reinforcement, divided with the number of bars (n), Figure 2 .

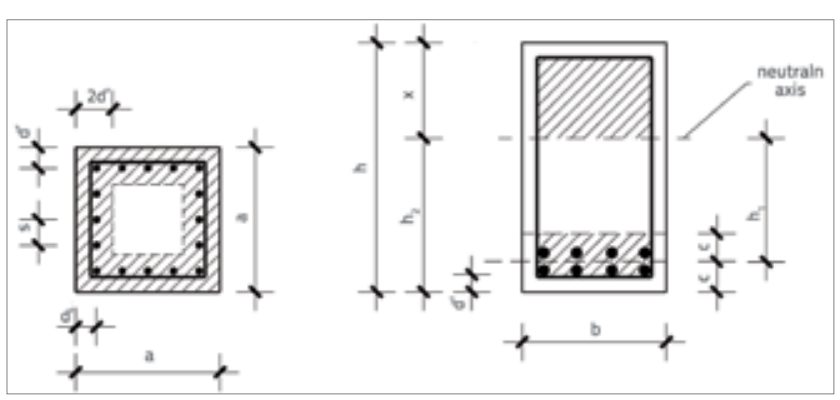

Figure 2. Examples for determining the participating zone of the reinforcement

$d^{\prime}$ - distance between the centre of gravity of the first row of bars and the tensile edge $(\mathrm{mm})$ 
$h_{2}$ - distance between the neutral axis and the tensile edge

$h_{1}$ - udistance between the neutral axis and the centre of gravity of tensile reinforcement.

The comparison between the maximum crack width according to [1, 2], and the typical one according to EN 1992-1-1, can be made by means of the modified expression for the mean width of cracks:

$w_{m}=8,3 \frac{h_{2}}{h_{1}} \sigma_{s} \sqrt[3]{A \cdot d^{\prime}} \cdot 10^{-6}$

The crack width limitation criterion, as based on the EN standard, can now be expressed as:

$\mathrm{w}_{\mathrm{k}}=\beta \times \mathrm{w}_{\mathrm{m}} \leq \mathrm{w}_{\mathrm{g}}$

where:

$\beta$ - is the factor for obtaining typical crack width $(\beta=1.7$ for service load or $\beta=1.3$ for forced deformations).

\section{Conclusion}

Over the past several years, and increasing interest has been registered in the world, and less in our country, for the construction of reinforced-concrete structures using lightweight concrete, based primarily on the use of lightweight aggregate. This is due to widely recognised economic and practical advantages of this material: lightweight aggregate concrete structures are lighter than normal-weight structures, which is significant for construction activity in earthquakeprone areas; they enable bridging of greater spans, and easier use of prefabricated elements, i.e. bridging of equal spans but using smaller-size elements. Latest research has shown that high strength concrete can also be made, without much difficulty, using the lightweight aggregate concrete. Unfortunately, the production and use of lightweight concrete structures is not followed by development of adequate regulations. American standards $\mathrm{ACl}-213 \mathrm{R}-03$ are most often used, while CEB-FIP model regulations and EN 1992-1-1 standards are less used. Recent studies made in Singapore have contributed to better understanding of beams made of lightweight aggregate concrete, and to the study of their computation possibilities, which is also made possible through contribution made by the authors of this paper.
Results of extensive experimental and theoretical studies conducted on the international level can be used to make some significant conclusions about the use of lightweight concrete made of crushed expanded clay:

1. Properties of lightweight aggregate concrete structures are very similar to those exhibited by normal-weight concrete, which is why they can almost always be used in circumstances when standard structures are normally used.

2. LWC beams are characterized by approximately $10 \%$ greater deflection when compared to those made of NWC. The deflection can be estimated using the same procedure that is typicallyapplied for NWC beams, the only difference being that a half of the effective elastic modulus $\mathrm{Ec} / 2$ is used instead of the full effective elastic modulus Ec. According to EN 1992-1-1, the following expression is proposed for elastic modulus of concrete: where: $h E=(\rho / 2200) 2$.

3. The strength values of the concrete based on aggregate composed of crushed expanded clay, to which silica fume and standard sand are added, can be equal to those obtained using the normal-weight concrete. This enables the use of calculation methods that are destined for NWC structures. In concrete terms, beams made of LWC of differing composition may have bearing capacities that are similar to those exhibited by NWC beams (comparison samples in experimental studies) and they present, during comparison, similar load - deflection diagrams.

4. Strengthening of compressive area in order to increase ductility of beams made of LWC can be achieved by closed ties and compressive reinforcement and, in this case, the effects are similar to those for NWC beams.

5. Experimental studies have shown that ductility of beams subjected to bending can be ensured by limiting the main tensile reinforcement, which is used for NWC beams with results that are similar to those obtained for LWC beams.

Because of proven economic and architectural benefits, an increased use of lightweight aggregate concrete is recommended, especially is earthquake prone areas, for the construction of safe, durable and usable structures. The lack of appropriate structural regulations for computations and construction should be solved as soon as practicable by production of standards based on existing results, and on additional studies and research. 


\section{REFERENCES}

[1] ACl Committee 213: Guide for Structural Lightweight-Aggregate Concrete (ACl 213R-03), American Concrete Institute, Farmington Hills, Ml, 2003, 38 pp.

[2] ACl Committee 318: Building Code Requirements for Structural Consrete (ACl 318-05) and Commentary, American Concrete Institute, Farmington Hills, Ml, 2005, 467 pp.

[3] BS 8110: 1: 1997, Structural Use of Concrete, Part 1-Code of Practice for Design and Construction, British Standards Institution, London, UK, 1997, 168 pp.

[4] EN 1992-1-1: Eurocode 2: Design of Concrete Structures, Part 1-1,-General Rules and Rules for Building, CEN, Brussels, December 2004, 225 pp.
[5] CEB-FIP Model Code 1990, Design Code, 1993, 437 pp.

[6] Sin, L.H., Huan, W.T., Islam, M.R., Mansur, M.A.: Reinforced Lightweight Concrete Beams in Flexure, ACI Structural Journal, Vol. 108, No.1, January-February 2011, pp 3-12.

[7] Park, R., Paulay, T.: Reinforced Concrete Structures, John Wiley \& Sons, New York, 1975.

[8] Tomičić, l.: Betonske konstrukcije, DHGK, Zagreb 1996.

[9] Kišiček, T., Sorić, Z., Galić, J.: Tablice za dimenzioniranje armiranobetonskih presjeka, GRAĐEVINAR 62 (2010) 11 str. 1001-1010 